\title{
Bir Terörle Mücadele Stratejisi Olarak Belediyelerde Kayyum ${ }^{a}$ Uygulaması
}

\author{
Tahsin Güler b, c , Abdullah Yılmaz d
}

\section{Özet}

Demokrasi kavramının, bireylerin/vatandaşların hak ve özgürlüklerini önceleyen doğası devlet-birey ilişkilerinde vatandaşa yakın olması bakımından yerel yönetimlere ayrı bir avantaj sağlamaktadır. Son yıllarda, seçimle işbaşına gelmelerine rağmen bir kısım belediyelerin terör örgütlerinin etkisi altında, vatandaşların oylarını, vergilerini ve demokrasi iklimini istismar ederek milli birlik ve bütünlüğü tehdit eden ayrı bir siyasal/ hukuksal yapı oluşturmaya çalıştıkları görülmüştür. 1 Eylül 2016 tarih ve 674 sayılı Kanun Hükmünde Kararnamede (KHK) yer alan hükümlere göre tespit edilen söz konusu belediyelere kayyum atanması uygulaması başlatılmıştır. Çalışmada kayyum atanması uygulamasının; yerel demokrasinin işleyişini baltalayan unsurların ortadan kaldırılarak demokrasinin yeniden işlerliğini sağlamaya dönük somut gelişmeleri/kazanımları barındırdığı, gerekçesinin ve uygulanma sürecinin uluslararası hukuk normlarıyla örtüştüğü, ayrıca terörle mücadelede etkin bir kamu politikası haline dönüştüğü değerlendirilmektedir.
Anahtar Kelimeler

Demokrasi

Kayyum

Uluslararası Hukuk

Terörle Mücadele

Makale Hakkında

Geliş Tarihi: 07.02.2019

Kabul Tarihi: 20.11.2019

Doi: 10.18026/cbayarsos.523837

\section{Trustee Application in Municipalities as a Strategy to Counterterrorism}

\begin{abstract}
The concept of democracy has a nature that prioritizes the rights and freedoms of individuals / citizens. Therefore, it gives a distinct advantage to the local governments that are close to the citizens in the state-individual relations. In recent years, although they came to power by election, some municipalities have exploited citizens' votes, taxes and the climate of democracy under the influence of terrorist organizations. In addition, these municipalities are trying to form a separate political / legal structure that threatens national unity and integrity. The application of the appointment of trustees to the mentioned municipalities according to the provisions of the Decree Law dated 1 September 2016 (KHK). In the study, the implementation of the appointment of the trustees; includes concrete developments/achievements to ensure the restoration of democracy by eliminating elements that hinder the functioning of local democracy. In addition, in the study it is evaluated that the reasons and implementation of this practice coincides with the norms of international law and is also becoming an effective public policy in the fight against terrorism.
\end{abstract}

Keywords

Democracy

Trustee

International Law

Counterterrorism

\begin{tabular}{r} 
About Article \\
\hline Received: 07.02.2019 \\
Accepted: 20.11.2019
\end{tabular}

Doi: 10.18026/cbayarsos.523837

\footnotetext{
a Kayyum, kayyım: "Bir malın yönetilmesi veya bir işin yapılması için görevlendirilen kimse” olarak tanımlanan kelimenin bazı hukuksal metinlerde (örn. Türk Ticaret Kanunu) "kayyım” bazı hukuksal metinlerde, kamu yönetimi literatüründe ve güncel yazılı/görsel medyada "kayyum" olarak kullanıldığı görülmektedir. Her iki kullanımda doğru olmakla birlikte yazarlar kelimenin Türk Dil Kurumu Güncel Türkçe Sözlükte kullanıldı̆̆ı şekliyle "kayyum" olarak kullanımını tercih etmişlerdir.

b İletişim Yazarı: gulert1043@gmail.com

c Doç. Dr., Balıkesir Üniversitesi, Siyaset Bilimi ve Kamu Yönetimi Bölümü, ORCID ID: https://orcid.org/0000-0002-7729-5172.

d Prof. Dr., Anadolu Üniversitesi Açık Öğretim Fakültesi, İktisadi ve İdari Programlar Bölümü, ORCID ID: https://orcid.org/0000-0003-3711-6915.
} 


\section{Giriş}

Batı'da, Soğuk Savaşın sürdüğü 1990'lara kadar komünizm tehdidine karşı tek boyutlu bir yapıda geliştirilen güvenlik stratejileri 2000'li yıllardan itibaren yerini çok daha karmaşık olan yeni tehditlere bırakmıştır (Brodeur, Gill ve Tollborg, 2016). Bu karmaşık tehditlerden birisi ve belki de en önemlisi olan terör tehdidi, kendisini özellikle 11 Eylül 2001'de New York ve Washington'a yapılan ve binlerce kişinin ölümüne yol açan saldırılar ile göstermiştir. Bu olay, aynı zamanda, terörün devletleri ve büyük coğrafyaları (Ortadoğu gibi) etkileyecek/karıştıracak uluslararası bir nitelik kazandığının da bir delili olmuştur. Dünyanın yeni bin yılda karşılaştığı, ulusal ve uluslararası güvenliği tehlikeye atan bu büyük meydan okumayı dini, siyasi, sosyal ve ekonomik pek çok sebep beslemiştir. Arap Baharı olarak adlandırılan süreçte bir kısım Kuzey Afrika ve Ortadoğu ülkelerinden Türkiye ve Avrupa'ya doğru gerçekleşen yoğun ve kontrolsüz göç hareketleriyle, göçe maruz kalan ülkelerin ulusal güvenliğine yönelik yeni tehditleri ve güvenlik politikalarında güncellemeleri beraberinde getirmiştir.

Son yıllarda bir takım büyük güçlerin özellikle Ortadoğu'da demokratikleşme kılıfıyla yönetimleri devirerek, bu bölgelerde kurduğu/kurdurduğu yeni terör örgütleriyle yarattığ 1 kaos ortamı ve sınırını dahi koruyamayan istikrarsızlaştırılmış komşu ülkeler Türkiye'nin uzun yıllardır mücadele ettiği ayrılıkçı terör örgütü ve destekçilerini cesaretlendirmiştir. Bu örgütler özellikle Türkiye'nin 2000'li yıllardan sonra önemli ilerlemeler kaydettiği demokrasi ve insan haklarının arkasına gizlenerek kendilerine yeni hareket alanları sağlamanın peşine düşmüşlerdir. Uzun yıllardır devam eden terör sorunun çözümü için, oluşturulan demokratik iklimin de etkisiyle başlatılan "çözüm süreci" terör örgütü ve destekçilerince istismar edilmiş, bir müddet devam eden çatışmasızlık süreci; terör örgütü tarafından rahat nefes alma, yeniden güçlenme ve özerklik ilan etme, şehirlerde hendekler kazarak kurtarılmış bölgeler oluşturma, şehir savaşlarıyla sivilleri kalkan olarak kullanıp terörün toplumsal ve psikolojik etkilerini artırma gibi yeni stratejileri hayata geçirmek için hazırlık süreci olarak kullanılmıştır.

Çözüm sürecinde demokrasinin gereği olarak seçimle işbaşına gelen belediyelerden bir kısmının terör örgütlerinin etkisi altında, vatandaşların oylarını, vergilerini ve demokrasi iklimini istismar ederek milli birlik ve bütünlüğü tehdit eden ayrı bir siyasal/ hukuksal yapı oluşturmaya çalıştıkları görülmüştür. Bu yaşananlara ilaveten 15 Temmuz 2016'da devletin bekasına yönelik en büyük saldırı olan darbe girişiminin mevcut sorunları daha da ağırlaştırması ülkede olağanüstü yönetime geçilmesini gerektirmiş, 1 Eylül 2016' da yürürlüğe giren 674 sayılı KHK ile terör örgütleri ile bağlantısı tespit edilen belediyelere kayyum atanmasına imkan tanınmıştır. Kayyum olarak atanan kişiler (uygulamada vali ve kaymakamlar) söz konusu belediyelerin başkanları sıfatıyla yerel kamu hizmetlerini üstlenmişlerdir. Bu süreçte kayyum uygulamasının terörle mücadeleye katkısı, bir güvenlik tedbiri olarak yerel demokrasiye etkisi ve hukuksal boyutunun incelenmesi uygulamanin bugünkü durumu, sürdürülebilirliği ve geleceği açısından önemli hale gelmiştir.

\section{Demokrasi- Güvenlik İlişkisi}

Şüphesiz, günümüzün modern dünyasında, Fouche'nin ${ }^{1}$ Napolyon'a yazdı̆̆ 1 mektupta önerdiği; "güvenlik güçlerinin, suçun önlenmesi ve bunun için henüz kanunun öngörmediği kontrol ve tutuklamaları yapabilmesi" ya da Weber'in, devletin hedeflerinin ve yapabileceklerinin hiç bir sınırının olmadığı dolayısıyla polis/güvenlik faaliyetlerinin, devletin 
gücünü en üst düzeye çıkarmak için bir araç olarak tanımlandığında bütün beşeri faaliyetleri kapsaması gerektiği (Brodeur ve Dupeyron, 2016) gibi düşüncelerden oldukça uzaklaşılmıştır. Demokratik bir toplumda, "ulusal güvenlik" olarak adlandırılabilecek çıkar ve faaliyetlerin zarar görmesini engellemek için güvenlik hizmetleri ve politikalarının oluşturulması son derece doğaldır. Ancak, burada, sonraki tartışmaların da çerçevesini oluşturan "demokratik toplum olgusu" en temel kavramı oluşturmaktadır. Nitekim kendi toprakları üzerinde etkin bir güvenlik kontrolü yürüten herhangi bir rejimin uyguladığı yöntemlerin ulusal güvenliği korumak adına olduğunu iddia edebilmesi, nihayetinde demokratik bir toplumun tesis edilmesi amacını baştan kabul etmesini/deklare etmesini gerektirir (Lustgarten, 2016).

Günümüzde demokratik ülkelerin hemen hepsinde güvenlik uygulamalarına bireyin temel hak ve özgürlükleri ile demokratik değerlerin korunmasını sağlamak amacıyla ve onları engellemeyecek ölçüde başvurulabileceğine ilişkin genel bir kabul vardır. Her ne kadar toplumda büyük korku ve paniğe yol açan ani ve olağanüstü olaylar karşısında -örneğin ABD'de 11 Eylül saldırıları, İngiltere'de metro ve parlamento önündeki bombalı saldırılar, Fransa'da kamuya açık alanlarda yaşanan terör saldırıları gibi- ülke yetkililerinin olağanüstü hal (OHAL) ilanına varan², demokrasiyi, temel hak ve özgürlükleri askıya alan uygulamalarıyla karşılaşılsa da (Güler ve Yılmaz, 2018) söz konusu ülkelerde demokratik değerlere yapılan vurgu güçlü kalmaya devam etmektedir. ${ }^{3}$

Küresel güvenlik tehditlerinin arttığı 2000'li yıllarla birlikte; ülkelerin güvenlik ve demokrasi kavramlarına ve bu kavramların birbirleriyle olan ilişkisine yaklaşımları farklılaşmış, diğer taraftan bu ilişkilerin ne kadar hassas bir dengeyi içerdiği de anlaşılmıştır. Nitekim, güvenlik politikalarındaki aşırılıklar demokrasiyi zedelerken, düşük yoğunluklu güvenlik politikaları ise bazı durumlarda bireylerin demokratik hak ve özgürlüklerini kullanabilmesi için gerekli olan güvenli ortamın sağlanmasını zorlaştırmakta, dolayısıyla kaosun hakim olduğu bir ortamda demokrasiden söz edebilmek mümkün olmamaktadır. Bu ilişki dengesinde -tarihsel olaylar göstermiştir ki- terazinin güvenlik kefesi her zaman daha ağır basmaya meyilli olmuştur.

Modern devlet, ortaya çıkmasından itibaren sahip olduğu meşru güç kullanma tekelinin bir tezahürü olarak kendisi de bir tehdit olabilme potansiyelini taşımakla birlikte, aynı zamanda temel hak ve özgürlüklerin en önemli ve meşru koruyucusudur. İnsanların güvenliklerini sağlama ve kamu düzenini koruma iddiasıyla yola çıkan devlet, güç kullanma tekelini üzerine alır ve bu konuda kendisine alternatif olabilecek herhangi bir oluşumun belirmesine izin vermez. Devletin bu denli büyük bir yetkiyi üzerine alması ve insanların da gücün merkezileşmesine rıza göstermeleri, büyük ölçüde güvenliklerinin sağlanması arayışı ile bağlantılıdır. Bu bakımdan, toplum olarak bir arada yaşayan insanların, olağanüstü bir durum olmadığı takdirde, herkesin uyması beklenen kuralların oluşturduğu bütünlüklü bir yapıyı ifade eden "düzen" içinde yaşamaları devletin sorumluluğu altındadır (Beriş, 2015).

Genel olarak; halkın güvenliği, tehlikeden uzak olması, toplumun iç ve dış tehlikelere karşı güvende olmasını ifade eden "kamu düzeni ve güvenliği" kavramı bu aşamada önem arz etmektedir. Ülke içinde kamu barışının, sosyal uyumun, hukuka saygının ve kamusal otoritelerin aldığ 1 kararların meşruiyetini sağlayan "kamu düzeni ve güvenliği" kavramı (Kalabalık, 2017) doğru ve yerinde uygulandığında, demokrasinin gelişmesine önemli katkılar yapmaktadır. Diğer taraftan temel demokratik hakların tanındığı, bireylerin hak arama/şikayet özgürlüklerini kullanmalarını sağlayacak barışçıl ve yapıcı mekanizmaların oluşturulduğu yerleşmiş bir demokrasi de bireylerin şiddete başvurma olasılıklarını azaltıcı 
bir etki yaratmaktadır (Shadi ve Brooke, 2010). Benzer şekilde terör tehdidi ya da güvenlik risklerinin azaltılmasında, güven ortamının oluşturulması ve bu konuda toplum kesimlerinin desteğini almak ve işbirliğini sağlamak son derece önemlidir (Bonino, 2016). Kısacası; kamu düzeni ve güvenliğini sağlamada polisiye tedbirler ve yasaklamalar tek başına yetersiz kalmaktadır. Bunun için bu tür süreçlerde güvenlik politikaları bir yandan toplum desteğini almaya yönelik sosyo-ekonomik politikalarla desteklenirken diğer yandan söz konusu tedbirlerin demokrasiye zarar vermemesi hususunda da hassasiyet gösterilmesi gerekmektedir.

\section{Terör ve Terörle Mücadele}

Günümüzde "terör" kavramının, üzerinde uzlaşılmış, evrensel bir tanımı bulunmamaktadır. Uluslararası alanda yüzden fazla tanıma sahip olan terör kavramı (Schmid ve Jongman, 1988) bu çeşitliliği birbirinden farklı siyasal, kültürel ve ideolojik sistemlerin rekabetine sahne olan uluslararası alanda kendisine atfedilen anlamın ülkeden ülkeye, coğrafyaya ve içinde yer alınan topluluk ve organizasyonun görüşüne göre farklılık göstermesinden almaktadır. ${ }^{4}$

Bugün terörün varlığı ve terörle mücadelede uluslararası alanda başarılı olunamamasının arkasında bu olgunun tanımında uzlaşılamamasının yanında bazı devletlerin terörü; hedeflerini gerçekleştirmede etkili bir araç olarak görmesi/kullanması yatmaktadır.

Türk Dil Kurumu tarafından "yıldırı; cana kıyma, malı yakıp yıkma, korkutma ve tedhiş" olarak ifade edilen terör kavramının en belirgin yönü, söz konusu eylemlerin şiddet içerikli olmasıdır. Her ne kadar terörün uluslararası ortak bir tanımı yapılmamış olsa da kavramın zarar verme ve şiddet içeren bir yönü bulunduğu hemen herkes tarafından kabul görmektedir. Bu bakımdan bombalı saldırılar, intihar saldırıları, silahlı saldırı, rehin alma, kaçırma ve bu tür eylemlere işaret eden tehditlerin terörizmi tanımlamakta kullanılan nesnel ölçütler olduğu konusunda dünyada ortak bir anlayış hakimdir. (Wilkinson, 2008). Bu durumu destekler biçimde Schmid ve Jongman'ın, 109 terör tanımını, içeriğinde en çok vurgulanan faktörler açısından inceledikleri çalışmalarında; "şiddet ve güç kullanımını içermesi” (\% 83), "siyasal amaçlarla yapılması" (\% 65), "korku yayması" (\% 51), "tehdit içermesi" (\% 47) kavramın en temel tanımlayıcı unsurları olarak belirlenmiştir (Schmid ve Jongman, 1988). Bunların dışında günlük yaşamda da çeşitli mecralarda bir takım olumsuz olayların -trafik terörü, maganda terörü gibi- terörle ilişkilendirilen kullanımları görülmektedir. Ancak bu tür kullanımlar literatürdeki terör kavramının karşılığı olmamakla birlikte yaşanan problemin şiddetine, vehametine ve can yakıcılığına vurgu yapmaktadır. Bu durum terörün ciddi ve toplumu bütünüyle etkileyen bir sorun olma özelliğini göstermektedir.

Terörizm, özellikleri bakımından kavramsal ve ampirik olarak diğer şiddet ve çatışma türlerinden ayrılmaktadır. Buna göre terörizm (Wilkinson, 2006);

$\checkmark$ Toplumda aşırı bir korku ortamı yaratmak için tasarlanır.

$\checkmark$ Kurbanlar önemsizdir, etkisi daha geniş hedeflere yöneliktir.

$\checkmark$ Siviller dahil olmak üzere rastgele veya sembolik hedeflere saldırıları içerir.

$\checkmark$ Anlaşmazlıkları, protestoları ve karşıtlıkları düzenleyen normları/kuralları ihlal eder.

$\checkmark$ Siyasi bir amaçla hükümetlerin, toplumların veya belirli sosyal grupların politik davranışlarını etkilemek için kullanılır. 
Buradan hareketle terörizm; arka planında bir takım hedef ve amaçların olduğu, planlayıcılarının/uygulayıcılarının bu amaçlara ulaşmak için eylemlerini gerekirse on yıllarca sürdürebildikleri sistemli saldırılar olarak tanımlanabilir.

Yukarıda belirtilen özellikleri yanında uluslararası bir düzenleme olması açısından önemli olan ve Türkiye'nin de taraf olduğu Avrupa Konseyi Terörizmin Önlenmesi Sözleşmesi'nde, [Council of Europe Convention on the Prevention of Terrorism, (CECPT)] terörizmin amacl; "halkı sindirmek veya bir hükümeti veya uluslararası örgütü bir eylemi yerine getirmeye veya getirmekten kaçınmaya haksız olarak zorlamak veya bir ülkeyi ya da uluslararası bir örgütü ciddi biçimde istikrarsız hale getirmek veya temel siyasal, anayasal, ekonomik ve toplumsal yapılarını yıkmaya çalışmak" şeklinde tanımlanmaktadır (CECPT, 2005).

3713 sayılı Terörle Mücadele Kanunu'nun (TMK) 1. maddesinde terör; “cebir ve şiddet kullanarak; baskı, korkutma, yıldırma, sindirme veya tehdit yöntemlerinden biriyle, Anayasada belirtilen Cumhuriyetin niteliklerini, siyasî, hukukî, sosyal, laik, ekonomik düzeni değiştirmek, Devletin ülkesi ve milletiyle bölünmez bütünlüğünü bozmak, Türk Devletinin ve Cumhuriyetin varlığını tehlikeye düşürmek, Devlet otoritesini zaafa uğratmak veya yıkmak veya ele geçirmek, temel hak ve hürriyetleri yok etmek, Devletin iç ve diş güvenliğini, kamu düzenini veya genel sağlığı bozmak amacıyla bir örgüte mensup kişi veya kişiler tarafından girişilecek her türlü suç teşkil eden eylemler" biçiminde tanımlanmıştır. Kanunun 2. ve 3. maddesinde terör suçlusunun tanımı yapılarak Türk Ceza Kanununda düzenlenen suçlardan hangilerinin terör suçu sayılacağı açıkça belirtilmiştir.

Terörle mücadele stratejileri terörizmin tanımında olduğu gibi ülkeden ülkeye değişiklik göstermektedir. Bu stratejiler terörün ortaya çıkış nedeni, terörist örgütün hedefleri, beslendiği kaynaklar, ulusal veya uluslararası alandan aldığı destekler, uyguladığı yöntemler vb. göre değişiklik göstermektedir. Örneğin; Türkiye'nin onlarca yıldır mücadele ettiği PKK terörüyle mücadele stratejisinde aşağıda belirtilen dört boyutun varlı̆̆ı söz konusudur (bilgesam.org, 2018).

a. Demokratikleşme boyutu: Özgürlükler temelinde demokratik değerlerin geliştirilmesi,

b. Sosyo-kültürel ve sosyo- ekonomik boyut: Terörü besleyen koşulların oradan kaldırılması ve halk desteğinin sağlanması,

c. Güvenlik boyutu: Teröristle mücadele ve silahlı terör örgütünün dağıtılması,

d. Uluslararası ilişkiler boyutu: Teröre sağlanan uluslararası desteğin kesilmesi ve terörle mücadeleye destek sağlanması.

Türkiye'de özellikle 2000'li yıllarla birlikte; başlıca tehditlerden olan PKK terörü ile mücadelede geçmişte ağırlık verilen güvenlikçi politikaların tek başına yetersiz kaldığı görülmüş, bu doğrultuda, terörle mücadele çok boyutlu politikalarla desteklenmiştir. Bu süreçte özellikle temel hak ve hürriyetlerin geliştirilmesi, hak arama mekanizmalarının oluşturulması gibi uygulamalar demokratik bir iklimin oluşmasına önemli katkı sağlarken terör örgütünün istismar ettiği sosyo- kültürel ve sosyo- ekonomik şartların iyileştirilmesi noktasında (örneğin; farklı dil ve lehçelerde eğitim yapılabilmesi, bölgeye özel yatırım teşvik ve istihdam politikalarının uygulanması, vb.) önemli ilerlemeler kaydedilmiştir. Teröre verilen uluslararası desteğin kesilmesi konusunda özellikle bu desteğin en yoğun şekilde verildiği Avrupa ülkeleriyle yoğun bir diplomasi yürütülmüş, terörün finansmanına ilişkin 
örgütün haraç alma ve uyuşturucu kaçakçılığıyla gelir elde etmesinin (başta Fransa ve Almanya), yayın organları yoluyla propaganda yapmasının (Danimarka'da Roj TV'nin kapatılması) önüne geçilmiş, Avrupa Birliği 2002' de PKK'yı terör örgütleri listesine almıştır (eur-lex.europa.eu, 2017).

Türkiye'nin güncel terörle mücadele yöntemi "terör örgütünün yalnızlaştırılması stratejisi" çizgisinde okunabilir. Bir yandan ülke içindeki güvenlik operasyonlarıyla örgütün konsolide etmeye çalıştığı KCK yapılanması sökülüp atılmakta, örgütün yurt içinden devşirmeye çalıştığ1 insan kaynağı ve mali destek ağları kesilmektedir. Türkiye bu güvenlik sürecine paralel olarak örgütün ulaşmaya çalıştığı toplumsal kesimlere yönelik yapıcı bir hizmet ve kimlik siyaseti de takip etmektedir (Duran, 2018). Her ne kadar başlangiçta daha çok kamu/yerel kaynakların terör örgütüne aktarılmasını önleyecek bir tedbir olarak düşünülmüşse de, kayyum uygulaması, sözü edilen yapıcı hizmet politikasının en önemli uygulamalarından birisi haline gelmiştir.

\section{Kayyum Uygulaması ve Terörle Mücadeledeki Yeri}

Türkiye, 2016 yılında merkezi yönetim-yerel yönetim ilişkilerinde geçmişte pek örneği görülmeyen, bazı belediyelere merkezi yönetim tarafından vali ve kaymakamların kayyum yönetici olarak atanması uygulaması ile karşılaşmıştır. Söz konusu uygulamanın özellikle, başarısızlıkla sonuçlanan "çözüm süreci” ile 15 Temmuz 2016'da "Darbe Kalkışması"nın yarattığ1 olağanüstü koşullarla ilişkili olduğu görülmektedir. Türkiye'de, toplumsal barış ve kamu düzeni açısından uzun yıllar bir tehdit unsuru olan terör sorununun çözümünde alternatif bir politika hamlesi olarak hayata geçirilmek istenen "çözüm süreci", çözümü istemeyen çevrelerin süreci baltalaması, terör örgütünce tırmandırılan terör ve şiddet olaylarının kamu düzeni ve ulusal güvenliği ciddi biçimde tehdit etmesi nedeniyle rafa kaldırılmış, bu şartlara 15 Temmuz 2016' da yaşanan darbe kalkışmasının da eklemlenmesiyle kamu düzeni ve milli güveliğin tehdit altında olduğu olağanüstü bir döneme girilmiştir. Bu süreçte bazı belediyelerin terör olaylarını finanse ettiği, lojistik destek ve imkan sağladığı, örgüt üyelerini gizlediği, koruduğu, terör örgütü üye ve sempatizanlarını istihdam ettiğine ilişkin yargıya intikal etmiş ve ulusal basında yer almış çok sayıda olayla karşılaşılmıştır. ${ }^{5}$

Terör örgütü bu süreçte kanlı ve yıkıcı eylemlerini şehir merkezlerine taşımış, konut dokunulmazlığını ihlal ederek birçok vatandaşı zorla evinden çıkarmış, göçe zorlamış, mahalle ve sokak aralarında hendekler kazıp barikatlar kurmuş, cadde ve sokaklara el yapımı patlayıcılar, bombalar yerleştirerek uluslararası sözleşmelerle, anayasa ve yasalarla güvence altına alınan yaşam hakkına tecavüz etmiş, başta eğitim ve sağlık olmak üzere halkın temel hizmetlere ulaşımını sekteye uğratmıştır. Terör örgütü bu faaliyetlerinde, belediye araçlarını kullanmış, belediyelerin iş makineleri ve malzemeleri ile hendekler ve barikatlar oluşturmuş, seçimle işbaşına gelen belediye başkanlıklarına eş başkan sıfatıyla Türk hukuk sisteminde tanınmayan/bulunmayan ve terör örgütünü temsil eden temsilciler görevlendirilmiş, belediyeler tarafından yapılan ihaleler terör yandaşlarına verilmiş, belediyeden ihale alanların terör örgütüne pay vermesini şart koşmuş, belediye çalışanlarının maaşlarından örgüte destek olan kuruluşlar için kesinti yapılmış ve terör örgütüne muhalif olan vatandaşlar belediye 
hizmetleri verilmeyerek (suları kesilerek, çöpleri toplanmayarak, otobüs seferleri yapılmayarak vb.) cezalandırılmıştır (icisleri.gov.tr, 2017).

01 Eylül 2016 tarih ve 674 sayılı KHK'nın 38. maddesi ile 5393 sayılı Belediye Kanununun 45. maddesine, "belediye başkanı veya başkan vekili ya da meclis üyesinin terör veya terör örgütlerine yardım ve yataklık suçları sebebiyle görevden uzaklaştırılması veya tutuklanması ya da kamu hizmetinden yasaklanması veya başkanlık sıfatı veya meclis üyeliğinin sona ermesi hallerinde 46. maddedeki makamlarca belediye başkanı veya başkan vekili ya da meclis üyesi görevlendirilir" şeklinde ek yapılmıştır. Bu fıkra gereğince; belediye başkanı veya başkan vekili görevlendirilen belediyelerde bütçe ve muhasebe iş ve işlemleri valilik onayı ile defterdarlığa veya mal müdürlüğüne gördürülebilir. Bu belediyelerde belediye meclisi, başkanın çağrısı olmadıkça toplanamaz. Meclisin, encümenin ve komisyonların görev ve yetkileri 31. maddede belirtilen encümen üyeleri tarafından yürütülür" hükümleri getirilmiştir.

$\mathrm{Bu}$ düzenlemeden hareketle; görevlendirmelerin büyükşehir ve il belediyelerinde İçişleri Bakanı, diğer belediyelerde vali tarafından yapılacağı, meclis, encümen ve komisyonların görevlerinin 5393 sayılı Belediye Kanununun 31. maddesinde belirtilen; belediye encümeninin memur üyeleri tarafından yürütüleceği belirtilmiştir.

Kayyum uygulaması, ilk olarak Diyarbakır'ın Sur ve Silvan ilçe belediyelerine kayyum atanmasıyla başlamış, uygulama İçişleri Bakanlığının 11 Eylül 2016'daki açıklamasıyla ikisi il belediyesi (Batman ve Hakkari) olmak üzere 28 belediyeye kayyum atanmasiyla genişletilmiştir. $\mathrm{Bu}$ atamaların $4^{\prime} \ddot{\mathrm{u}}$ FETÖ, 24'ü ise PKK-KCK terör örgütleriyle ilişkili belediyelere yapılmıştır. Söz konusu belediyelerin 12'sinin başkanı atama tarihinde tutuklu bulunmaktadır. İçişleri Bakanlığı, kayyum atamalarına ilişkin; “Demokrasi ve hukuk devleti anlayışında millet iradesinin yerel yönetimlere yansıması esastır. Ancak belediyeler; vatandaşımızın kullandığı oyu, verdiği vergileri ve demokrasinin sunduğu iklimi istismar ederek ülkemizin birlik ve bütünlüğüne kasteden terör örgütlerinin etkisi altına giriyorsa, milli iradeyi gasp edenlere karşı tedbir almak devletin asli görevidir. Vatandaşlarımızın verdiği vergilerle oluşan kaynaklar ve verdiği oyla oluşan siyasi irade, terör örgütlerine devşirilemez" açıklamasıyla kayyum uygulamasının gerekçesini açık bir şekilde belirtmiştir. 674 Sayılı KHK gereğince İçişleri Bakanlığı ve Valilikler tarafından görevlendirilen belediye başkanları ve belediye meclis üyelerinin sayıları aşağıdaki tabloda yer almaktadır.

Tablo 1. 674 Sayılı KHK Gereğince Görevlendirilen Belediye Başkan ve Belediye Meclis Üye Sayıları

\section{İ̧̧işLERİ BAKANINCA GÖREVLENDIRILEN}

Büyükşehir Belediye Başkanı

Büyükşehir İlçe Belediye Başkanı

Büyükşehir İlçe Bel. Mec. Üyesi

İl Belediye Başkanı

İl Belediye Meclis Üyesi

\section{VALILERCE GÖREVLENDİRILEN}

3 İlçe Belediye Başkanı 44

22 İlçe Belediye Meclis Üyesi 46

54 Belde Belediye Başkanı

6 Belde Bel. Meclis Üyesi

Kaynak: (Keleş ve Özgül, 2017) 40 
2018 yılı itibariyle sayısı 94 olan kayyum atanan belediyelerde kayyum atamasıyla birlikte; terörle mücadele işlevinin "organizasyonel" ve "toplumsal analiz" düzlemlerini içeren iki temel amaç üzerine kurulduğu görülmektedir. Bunlardan birincisi olan "organizasyonel amaç" doğrultusunda; örgütün kurmaya çalıştığı siyasi otorite belediyelere yapılan kayyum görevlendirmeleriyle engellenmiş, terör örgütünün belediyeler üzerinden oluşturduğu propaganda ve lojistik ağı ortadan kaldırılmıştır. Bu ilk amaç doğrultusunda terörle mücadele açısından terörün yakın nedenleri yani örgütün belediyelere sirayet eden illegal yapısı temizlenmeye çalışılmıştır. İkinci amaç doğrultusunda ise bireyleri radikalleşme, terör örgütüne destek verme, hatta bizzat katılmaya iten etkenler ortadan kaldırılmaya çalışılmaktadır. Bu doğrultuda öncelik bölgedeki ekonomik mahrumiyetin çeşitli bakanlık ve belediyelerin koordinasyonuyla ortadan kaldırılması, bölgedeki salt etnik kimlik boyutuna indirgenmiş sosyal-psikolojik kategorizasyonu çapraz kesen bütünleştirici bir kimlik inşası, terör örgütü kontrolündeki mecralara alternatif sosyalleşme ve mobilizasyon kanalları oluşturulması gibi adımlar atılmaktadır (Alptekin ve İlhan, 2018).

Sosyalleşme ve mobilizasyon kanalları içerikli ikinci amaç bağlamında; suyu akmayan il, ilçe ve beldelerde içme suyu şebekelerinin yapımı ve onarımı, biriken çöplerin toplanması, yüksek kaliteli asfalt ve parke yolların yapımı, çocuk parkları, taziye evleri, aydınlatma, peyzaj, gençlik ve aile merkezleri, kadın kültür merkezleri, semt spor sahaları, otopark ve otogarlar, konferans salonları, kütüphane, yurtlar, vb. belediye hizmetlerinin halka sunulması sağlanmıştır (icisleri.gov.tr, 2018). Belediyeler bünyesinde futbol, voleybol ve hentbol takımlarının kurulması, çocuklara ve gençlere yönelik tiyatro gösterimleri, gezici çocuk kütüphaneleri, halı saha yapım projeleri, çocuklar ve gençler için korolar oluşturulması gibi kültürel ve sportif etkinliklerin yaygınlaştırılması sağlanmıştır (icisleri.gov.tr, 2017). Kayyumlar eliyle gerçekleştirilen hizmetler ve yatırımların güncel mali büyüklüğü aşağıdaki tabloda yer almaktadir.

Tablo 2. Kayyum Atanmasından Sonra (94 Belediyede) Kayyumlar Eliyle Yapılan Hizmet ve Yatırımların Mali Büyüklüğü

\begin{tabular}{ll}
\hline YAPILAN HIZMETIN TÜRÜ & MÍKTARI \\
\hline Hizmet ve Yatırım Tutarı & $7.513 .123 .044 \mathrm{TL}$ \\
Asfalt Yol & $9.666 \mathrm{~km}$ \\
Stabilize Yol & $18.000 \mathrm{~km}$ \\
İçme Suyu Hattı & $5191 \mathrm{~km}$ \\
Kanalizasyon Şebekesi & $4000 \mathrm{~km}$ \\
Park (çay bahçesi, park, çocuk parkı) & 2644 adet \\
Kadın Kültür Merkezi & 161 adet \\
Taziye Evi & 1649 adet \\
Gençlik Merkezi & 70 adet \\
\hline
\end{tabular}

Kaynak: İçişleri Bakanlığının 06.11.2018 tarihli basın açıklamasından oluşturulmuştur. 
Kayyum görevlendirmelerinin terör ve terörle mücadelede en önemli etkisi; doğrudan örgüt ağını çökertmenin yanında, insanları örgüte iten sosyal, ekonomik, kültürel, vb. daha örtülü ve dolaylı nedenleri ortadan kaldırmaya yönelik olmuştur. Bunun için topluma daha etkin hizmet sunmak ve sosyalleşme imkanları sağlamak yoluyla bölge toplumunun sosyoekonomik seviyesi geliştirilmeye çalışılmaktadır. Bu bağlamda öne çıkan ve yukarıda detayları belirtilen çalışmalar aşağıdaki gibi başlıklandırılabilir (Alptekin ve İlhan, 2018):

$\checkmark$ Bölge insanına eğitim bursu ve çeşitli ayni ve nakdi yardımlarla doğrudan ekonomik yardım sunulmaya çalışılması; meslek edindirme kursları ve doğrudan yatırımla istihdam yaratılması,

$\checkmark$ Altyapı yatırımları ve yatırım özendirici politikalarla bölgenin kalkındırılması,

$\checkmark$ Açılan spor tesis ve okulları, gerçekleştirilen yurt içi geziler, dini/manevi etkinliklerle alternatif sosyalleşme kanallarının kurulması,

$\checkmark$ Bunlara ilaveten yürütülen kadın ve gençlik merkezleri faaliyetleriyle terör ve şiddet sarmalından uzak "normal" bir yaşam ortamının tesisi.

Kamuoyunda kayyum görevlendirmesi olarak bilinen bu uygulamayla; terör örgütüne belediyeler üzerinden aktarılan para ve insan kaynağ 1 desteğinin engellenmesi; asker ve kolluk görevlilerinin operasyonel desteğiyle birlikte PKK/KCK terör örgütünün etkinliğini, eylemselliğini kaybetmesi; terör örgütüne katılım oranının son otuz yılın en düşük seviyesine inmesi uygulamanın terörle mücadelede etkili bir politika işlevi gördüğünü göstermektedir.

\section{Kayyum Uygulamasının Hukuksal Boyutu}

Uluslararası alanda insan hakları ve temel özgürlüklerin korunmasına yönelik en temel sözleşme olan İnsan Hakları Evrensel Beyannamesi'nin 3. maddesi (un.org, 2018) ve Avrupa İnsan Hakları Sözleşmesi'nin (AİHS) 2. Maddesinde; her ferdin yaşama hakkına sahip olduğu ve bu hakkın yasayla korunacağ 1 belirtilmektedir. AİHS'nin 15. maddesinde ülkelerin; savaş veya ulusun varlığını tehdit eden başka bir genel tehlike halinde durumun gerektirdiği ölçüde ve uluslararası hukuktan doğan başka yükümlülüklere ters düşmemek koşuluyla, yaşam hakkı, işkence yasağı, kölelik, zorla çalıştırma yasağı ve kanunsuz ceza verme dışında sözleşmede öngörülen yükümlülüklere aykırı tedbirler alabileceği belirtilmektedir (AİHS, www.echr.coe.int, 1950).

Türkiye'nin de taraf olduğu diğer bir hukuk metni olan "Avrupa Konseyi Terörizmin Önlenmesi Sözleşmesi" ne göre taraf ülkelerin "Terör Suçunun İşlenmesine Alenen Teşvik" (5. md), “Terörist Saflara Katma" (6. md) ve “Terörizm İçin Eğitim” (7. md) başlıklarında belirtilen suçlara iştirak eden tüzel kişilerin sorumluluğunu ihdas eden önlemleri kabul edeceği ve imzacı tarafın yasal ilkelerine bağlı olarak, tüzel kişilerin sorumluluklarının cezai, medeni veya idari nitelikte olabileceği kabul edilmiştir (KDGM, 2013).

İçişleri Bakanlığı raporları, basına yansıyan çeşitli olaylar ve mahkeme kararlarından; kayyum atanmasına konu olan belediyelerin terör örgütlerine yardım ve yataklık yaptığı, bölge insanının yaşama hakkına yönelik terörist eylemlere destek verdiği, terör suçunun işlenmesini alenen teşvik ettiği, terörist saflara insan kaynağı, eğitim ve finansman desteği sağladığ 1 anlaşılmaktadır. Uluslararası hukuk metinlerinde bu eylemlere maruz kalan ülkenin cezai, medeni ve idari tedbirler almasına açıkça onay verilmektedir. Nitekim uluslararası hukuka uygun olarak kayyum görevlendirmelerin Anayasanın 15. maddesinde; “...olağanüstü 
hallerde, milletler arası hukuktan doğan yükümlülükler ihlal edilmemek kaydiyla..." hükmüne uygun olarak çıkarılan 674 sayılı KHK ile 5393 sayılı Belediye Kanunu'na ve bu Kanuna yapılan ek maddelere istinaden uygulamaya konulduğu görülmektedir. $\mathrm{Bu}$ bağlamda, belediyelere kayyum atanması uygulamasının; olağanüstü (savaş, seferberlik, sıkıyönetim ve olağanüstü haller) bir durumun varlığıyla ortaya çıktığı, dokunulmaması/korunması gereken çekirdek alanların (yaşam hakkı, işkence yasağı, kölelik ve zorla çalıştırma yasağı) dışında kalan düzenlemeleri içerdiği, kapsamı ve içeriği bakımından kısmi, tutarlı ve durumun gerektirdiği ölçüde olduğu, uygulamanın özellikle bölge halkının can güvenliğinin ve kamu hizmetlerine ulaşımının sağlanması açısından son derece yararlı sonuçlar doğurduğu, terör olaylarının minimize edilerek gündemin ilk sırasından çıkarıldığı ve bölgede normalleşmenin sağlandığı görülmektedir.

\section{Sonuç}

Günümüzde terör ve terörle mücadele olgusu, tüm dünyanın gündeminde yer alan, ülkelerin yönetim süreçlerinde sürdürülebilir mutlak politikalar geliştirmek zorunda oldukları bir olgudur. Olgunun bu denli önemli oluşu başta devlet düzeni ve toplumsal yaşam olmak üzere pek çok yapıyı olumsuz etkileme kapasitesine sahip olmasıyla açıklanabilir. Nitekim demokratik bir yapının kurulmasını sağlarken zor olan, bir yandan bu yapıyı besleyecek özgürlük iklimini muhafaza ederken diğer yandan bu yapıyı koruyacak güvenlik politikalarını yeterli ölçüde uygulayabilmektir. Öyle ki çalışmanın özünü teşkil eden, belediyelere kayyum atama uygulamasının da bu tür bir zorunluluğun sonucu olarak ortaya çıtı̆̆ı görülmektedir.

2000'li y1llardan sonra yaşanan demokratikleşme süreciyle temel hak ve hürriyetlerin geliştirilerek özgürlük ortamının sağlanmasında önemli mesafeler alınmışken ulusal güvenliği tehdit eden terör örgütünün halkın yerel ve ortak ihtiyaçlarını karşılamak için demokratik usullerle seçilen bazı belediye yönetimlerini tahakkümü altına alması, bu belediyelerde milletin kaynaklarının terör örgütlerine aktarılmasına hizmet eden gayrimeşru bir yapı oluşturması, devletin terörle mücadelede yeni ve farklı bir strateji uygulamasını gerekli kılmıştır. Yaklaşık iki yıllık bir geçmişi olan belediyelere kayyum atanması uygulaması değerlendirildiğinde; kayyum atanan belediyelerde, yerel hizmetlerin sunumunda önemli ilerlemeler sağlanmış, terör örgütünün finansman, insan kaynağı ve lojistik desteği kesilmiş, terör baskısının kalkmasıyla bu beldelerde yaşam büyük oranda normale dönmüştür. Son derece başarılı bir yöntem olmakla birlikte belediyelere kayyum atanması demokratik rejimlerde olağanüstü dönemlerin geçici ve zorunlu bir stratejisi olarak görülmektedir/görülmelidir. Bu bakımdan uygulamanın; yerel seçimlerde, yasalara saygılı, halkın yerel ihtiyaçlarını esas alan, terör odaklarıyla hiçbir ilgisi ve bağlantısı bulunmayan yönetimlerin seçilmesi durumunda kaldırılacağı/kaldırılması gerektiği düşünülmektedir.

\section{Kaynakça}

Alptekin, H. \& İihan, B. (2018). Kayyum atanan belediyelerin Pkk terörü ile mücadeledeki rolü, Ankara, SETA Yayınları 110

Anadolu Ajansı (2017). "Fransa'da 719 gün süren ohal kalktı", https://www.aa.com.tr/tr/dunya/fransada-719-gun-suren-ohal-kalkti/953699, (02.12.2018) 
Avrupa Konseyi (1950). Avrupa insan hakları sözleşmesi

Erişim adresi https://www.echr.coe.int/Documents/Convention_ENG.pdf

Avrupa Konseyin (2017). Avrupa konseyi terör listesi

Erişim adresi https://eur-lex.europa.eu/legal-content/en/TXT/PDF/?uri=CELEX:32017D14 26\&from=EN

Beriş, H. E. (2015). Kamu düzeni, güvenlik ve demokratikleşme, Güvenlik Çalışmaları Dergisi, Cilt: 17, Sayı: 1 s. $1-18$

Bilgesam (2018). Terörle mücadele stratejisi

Erişim adresi http://www.bilgesam.org/Images/Haberler/HaberlerDiger/terorlemucadele ozet.pdf

Birleşmiş Milletler (2018). İnsan hakları evrensel beyannamesi

Erişim adresi http://www.un.org/en/universal-declaration-human-rights/index.Html

Bonino, S. (2016). “The British state'security syndrome' and Muslim diversity: challenges for liberal democracy in the age of terror", Contemporary Islam 10(2), 223-247

Brodeur, J. P., Gill, P. \& Tolborg, D. (2016). Democracy, law and security, (Ed.), Jean-Paul Brodeur, Peter, Gill and Dennis Tollborg, Routledge, 2002, London. ProQuest book Central, Available form http://ebookcentral.proquest.com/lib/balikesir-ebooks/ detail.action?doc $\mathrm{ID}=4817090$

Brodeur, J. P. \& Dupeyron, N. (2016). Democracy and secrecy: intelligence the French community, (Ed.), Jean-Paul Brodeur, Peter, Gill and Dennis Tollborg, Democracy, law and security, Routledge 2002. London Pp. 9-29, ProQuest Ebook Central, Available from http://ebookcentral.proquest.com/lib/balikesir-ebooks/detail.action?docID=4817090

Çakır, B. (2008). "Fransız Devrimi'nde Joseph Fouche'nin siyaseti ve siyasetinin kişiliği ile özdeşleşen boyutu", Sosyoloji Konferansları, Sayı: 38, s. 29-55

Duran, B. (2018). Takdim, Etnik terör ve terörle mücadele stratejileri: Ira, Eta, Tamil Kaplanları ve Pkk içinde, Strateji Araştırmaları Serisi 5, SETA

Güler, T. \& Yilmaz, A. (2018). “Yerel demokrasi-güvenlik sarmalında yerel yönetimler: Türkiye'de belediyelere kayyum atanması pratiği", Elektronik Sosyal Bilimler Dergisi, Cilt: 17, Say1: 68 , ss. $1801-1816$

Güneş (2016). Büyük ihanet ortaya çıtı, Güneş, 07 Nisan 2017.

Erişim adresi http://www.gunes.com/gundem/12-polisin-sehit-edildigi-hain-saldiridabelediye-araci-kullanildi-778135

İçişleri Bakanlığı (2018). Kayyumlara ilişkin asılsız haberler basın bilgilendirmesi

Erişim adresi https://www.icisleri.gov.tr/basin-aciklamasi06112018

İçişleri Bakanlığı (2017). Terör nedeniyle belediyelere yapılan görevlendirmeler

Erişim adresi https://isay2.icisleri.gov.tr/kurumlar/strateji.gov.tr/deneme/YAYINLAR/\% C4\%B0\%C3\%87ER\%C4\%B0K/belediyeler\%20redakteSON.pdf

Kalabalık, H. (2017). İnsan hakları ve kamu özgürlükleri, (Ed.), Nazmiye Özenbaş (Ed.). Anadolu Üniversitesi Yayın No: 3434 
KDGM (2013), Bütün boyutlarıla terörizmin önlenmesi Avrupa sözleşmesi, Kamu Düzeni ve Güvenliği Müsteşarlığı Yayınları: 2, Ankara

Keleş, R. \& Özgül, C. G. (2017). Belediye organlarına “kayyım” atamaları üzerine bir değerlendirme, Ankara Üniversitesi SBF Dergisi, Cilt 72, No. 2, S. 299 - 313

Le Monde (2018). Gilets jaunes » : après les violences, le gouvernement tente de rebondir Avaliable from https://www.lemonde.fr/societe/article/2018/12/02/gilets-jaunes-apres-lesviolences-du-1er-decembre-le-gouvernement-face-a-une-crise-majeure_5391627_32 24.html

Lustgarten, L. (2016). National security and political some thoughts on values, ends and law, (Ed.), Jean-Paul Brodeur, Peter, Gill and Dennis Tollborg, Democracy, law and security, Routledge, 2002, London. Pp 319-334 ProQuest Ebook Central, Avaliable from http://ebookcentral.proquest.com/lib/balikesir-ebooks/detail. action?docID=4817090.

Milliyet (2017). Suikastçı terörist belediye çalışanı çıktı, Milliyet, 11 Ağustos 2017.

Erişim adresi http://www.milliyet.com.tr/suikastci-terorist-belediye-gundem- 2500461/

Sabah (2016). Terör saldırısında belediye araçları kullanılmış, Sabah, 10 Temmuz 2016.

Erişim adresi https://www.sabah.com.tr/gundem/2016/07/10/terorsaldirisinda-belediyearaclari-kullanilmis

Schmid, A. P. \& Jongman, A. J. (1988). Political terrorism: a new guide to actors, authors, concepts, data bases, theories and literature, New York, Taylor\& Francis

Shadi, H. \& Brooke, S. (2010). Promoting democracy to stop terror, revisited, Policy Review, Sayı: 159 , s. $45-57$

Wilkinson, P. (2006). Terrorism versus democracy the liberal state response, Second Edition, Routledge, İngiltere

\section{Açıklamalar}

1 1759-1820 yılları arasında Fransa'da yaşamış olan Joseph Fouche, her dönemin adamı olması özelliğiyle tarihin en önemli politikacılarından biri olarak Fransız Devriminde sırasıyla monarşist, jirondist, jakoben, thermidorcu (Robespierre ve Jakobenlerin iktidardan indirildikleri darbeye verilen ad), Direktuvarcı ve Napolyoncu olmuştur (Çakır, 2008: 29).

${ }^{2}$ Fransa'da 13 Kasım 2015'te gerçekleştirilen ve 130 kişinin hayatını kaybettiği terör saldırılarından sonra ilan edilen OHAL, 719 gün sonra Kasım 2017'de kalktı. Ancak OHAL'in yerine getirilen Terörle Mücadele Yasası, OHAL'i neredeyse kalıcı hale getiren hükümler içermektedir (www.aa.com.tr. 2017). Fransa'da, 2018 yılının sonlarında, "sarı yelekliler" olarak adlandırılan grupların öncülüğünde akaryakıt zamlarını protesto etme temelinde haftalardır süren gösteriler güvenlik güçleriyle çatışmaya dönüştü. Ülke genelinde yüzbinlerce kişinin katıldığı gösterilere karşı Macron başkanlığında yapılan kriz toplantısında olağanüstü hal ilanı da seçenekler arasında yer aldı (www.le monde,.fr, 2018).

${ }^{3}$ Diğer taraftan özellikle İngiltere'de ortaya konan terörle mücadele politikalarının toplumu disipline eden bir ceza devletini ortaya çıarma tehlikesini de hissettirdiğini vurgulamak gerekir (Bonino, 2016: 232).

${ }^{4}$ Uluslararası hukukta üzerinde anlaşılmış ortak bir terör tanımının olmaması ve olaylara objektiflikten uzak yaklaşımlar "herkesin teröristi kendine" anlayışını/anlayışsızlığını getirmiştir. Örneğin İsrail 
Devleti'nin terörist olarak gördüğü Filistinlilerin mücadelesi İslam dünyası için özgürlük mücadelesi olarak nitelendirilmekte, Türkiye'de onlarca yıldır terörist faaliyetlerde bulunan PKK'nın birçok Avrupa ülkesi tarafından özgürlük savaşçısı olarak görülmesi, yine Türkiye'nin terörist olarak nitelediği PKK'nın uzantısı PYD/YPG'nin ABD tarafından terörist sayılmaması ve birlikte çalışılması gibi farklı tutumlarla karşılaşılmaktadır.

${ }^{5}$ Basına yansıyan olaylardan bazıları şunlardır; Ağustos 2016'da Şırnak'ın Cizre ilçesinde 12 polisin şehit edildiği ve 10 ton patlayıcı kullanılarak gerçekleştirilen saldırıda Şırnak Belediyesi'ne ait hafriyat kamyonunun kullanıldığının anlaşılması (Güneş, 2016); Mardin'in Artuklu ilçesindeki Cevizlik Jandarma Karakoluna yönelik PKK'lı teröristlerce patlayıcı yüklü araçla düzenlenen saldırıda kullanılan aracın Mazıdağı Belediyesi'ne ait olduğu tespit edildi (Sabah, 2016); Siirt Valisi Ali Fuat Atik, Baykan ilçesinde gerçekleştirilen hava operasyonunda etkisiz hale getirilen teröristlerden birinin DBP'nin yönettiği Siirt Belediyesi'nde çalıştığını, belediyeye kayyum atanmasıyla işine son verildiğini belirtti (Milliyet, 2017). 